\title{
THE LIFE OF A GIRL IN CHINA
}

\author{
By Miss Li Yieni Tsao, M. D.
}

Within the last thirty years, a great deal of literature has been produced on China and things Chinese. The prevailing tendency among writers is to belittle and condemn. Each writer tries to draw his own conclusion from a carefully selected set of facts ready for his manipulation. One-sided facts could very successfully hoodwink the readers who are not acquainted with other than what are furnished. However, it has been generally acknowledged that critics usually present the dark side more energetically than the bright. Recently, sociological studies have broadened the minds of men so that the attitude of one people for another has changed from one of off-hand condemnation to sympathetic interest. In depicting the life of a Chinese girl in China, the writer would neither defend the position of her country-women against the onslaught of critics, nor paint a rosy picture, but make a faithful description of the situation, with the hope that some of her readers might volunteer to furnish help in breaking down the bad religious and social customs that fetter the girls and women of China. Realizing the difficulty in ameliorating the condition of Chinese women without first locating the chief social bulwarks that have been responsible for it, it is with a deep sense of responsibility that the writer proceeds with the discussion.

Since it is not the writer's intention to prove any definite conclusion advocated, it would be well to lay down at the start certain fundamental sociological principles that have been generally acknowledged and which might likely serve to elucidate the situation.

I.-Man and woman differ, as Tennyson has it: "Woman is not man undeveloped but diverse." This is universally true.

II.-A. The society that is based upon the old, is conservative. This is true of China.

B. The society that is based upon the young, is progressive. This is true of the West.

In China the young obeys the old, in the West the old yields to the young. 
III.-A. Chinese home-life emphasizes solidarity.

B. Western home-life emphasizes individualism. The Chinese family is a co-operative community which necessitates a constant self-sacrifice. The western family is an independent unit which develops a selfreliant aggressive spirit.

IV.-In the struggle for existence, the protected becomes weak; the unprotected strong.

Space does not permit the amplification of the above statements, but a little reflection would be sufficient to convince any one of their validity as they have been universally admitted. However, in the course of description, whenever occasion arises reference will be made to them explicitly. Wherever possible, comparisons between the eastern and western life will also be used. China is now undergoing a period of transition and so many conditions have changed that one is often placed on the horns of a dilemma in g.ving a faithful portrayal; one is either tempted to present too much of the modern life or else of the life prior to the influence of Christianity and western culture. Inasmuch as modern ideals have only affected the coast provinces and. treaty ports, it is deemed advisable to depict a Chinese girl's life which was universally true throughout China some thirty years ago.

\section{A. Early Childhood}

The advent of a girl in a Chinese family has rarely been an event of joy as compared with that caused by the arrival of a boy; of course this is not true of Chinese Christian homes. Aside from the economic, the chief reasons for disappointment are because a daughter cannor offer the annual ancestral sacrifice, glorify the family by official appointment through literary attainments, and perpetuate the family name. In a society where reverence for the old (II A) has become ancestral worship, the above considerations assume an alarming degree of importance.

In general, the baby girl receives the same tender care as a boy would as soon as maternal philoprogenitiveness overcomes the first impulse of disappointment as shared by friends and relatives alike. $U_{p}$ to the age of five or six, the child participates equally in the privileges of her brother, excepting those that would tend to make her a "Tomboy." (I). At the age of five or six, however, the line 
of demarcation becomes more distinct between the boy and the girl. This landmark is the wicked and senseless custom of foot-binding, which has done much to weaken the constitution of our women and harden the natural love of mothers for their young. A pair of small feet though at first considered as a form of beauty, has, in course of time, become a mark of gentility, and therefore all families which could lay claim to a genteel ancestry would feel duty bound to cramp the toes of their girls. This custom is by no means universal, for the Manchus of the north, the Hakkas of the south, and the agricultural class in many sections of the country do not appreciate this form of "hobble" beauty.

The duty of administering this unnatural torture devolves upon the mothers who, in stamping their own flesh with the mark of gentility, have for generations gone about the task with dogged determination and oftentimes with many a bitter tear. Fond fathers have interceded in vain against this invulnerable custom which has served time and again as a cause for an unquiet house. Rare exceptions are known when both parents agree to supply their daughters with stilted shoes as a measure to defeat the practice. Generally, the mothers have forgotten their past sufferings, and feeling proud of their own small feet, apply bandages to their daughters' feet desperately. On the other hand, the child is henceforth placed in a different sphere from the boy. Cries, protests, lamed feet and a sedentary life label her as a Chinese girl.

\section{B. Her Education}

The education received by the Chinese girl before the advent of the Mission Schools and the modern school system was a negligible quantity. Kindergarten and domestic science were unknown from the modern educational standpoint; physical education was impossible on account of the bandaged feet; for even walking was too painful at the beginning. Under the old tutorial system, education had as its aim, the training of men for business or government service, and since women were not supposed to receive official positions, their education was therefore not deemed as absolutely necessary. This, however, does not imply the utter negligence of female education; for loving parents had often given their daughters the rudiments of knowledge in common with their sons under the 
same family or village tutor, and sometimes even an advanced literary education was imparted to them.

Under such circumstances, the children of the ignorant and the poor are wholly neglected as a matter of course, and it is only with the advent of universal and compulsory education that this condition can be remedied. But in the upper and middle classes, girls generally go to school till the age of adolescence when it was considered improper for them to be seen constantly out of doors, so it is only in families where tutors could be afforded that their education so far as reading and writing are concerned may be prolonged. The curriculum covered coincides with what a boy generally learns up to the age of twelve or fourteen, excepting a few books which have special reference to the duties of a girl. This implies a general knowledge of reading and writing letters and some ciphering. After that time till marriage, the greater part of the time would be devoted to sewing, embroidery, cooking and general domestic art. These duties often mean an endless task in helping to furnish the household with simple articles of dress and food, such as hats, shoes, socks, shirts and preserves, pastry, etc. In households of reduced circumstances piecework in sewing, pastry, lanterns, making matchboxes, weaving baskets and the minor employment of the silk and tea industries might be carried on as a means of keeping the wolf out (III A).

\section{Her Social and Moral Life}

A Chinese girl has very little social life to speak of. This is also true of the boy when compared with Tom Brown at Rugby. In fact, the rigid paternalistic oversight (IV) has reduced the initiative of Chinese youths to a considerable extent. As eastern society is based upon the principle of filial piety, it has become almost a second nature to obey one's parents, elders and superiors. While obedience is a good discipline, pushed to the extreme it has a weakening effect upon the moral fibre of the young. Often times, children have to put up with unreasonable parents just because custom requires it, and any infringement would be eyed with disapprobation from all. "Well, it may not be the best, but what of that, she is after all your mother," is a phrase constantly heard addressed to a revolting child. Westerners have watched with great surprise 
the meek submission with which Chinese children, and even adults, receive the reasonable and unreasonable chastisement of their parents. It is likewise a surprise for the easterners to see the western youths behave towards their parents. In the East, society is based upon the old, and in the West, upon the young; thus in the former the young has no voice while in the latter, the old is considered a back number (II A, B).

Since of children is required so much obedience, a boy's climbing, swimming and fighting instincts are curbed as far as the apron strings could reach. As girls lead a much more indoor life, constant supervision has made freedom of action almost impossible. Physical exercise beyond the most rudimentary such as is seen in the kindergartens of the West, is practically unknown. The few social enjoyments usually mean dressing up and being on behavior. The chief occasions that send a ripple of cheer and excitement through the heart of a Chinese girl would be attending a fair, a theatrical performance, a sewing circle, a birthday or a wedding. Short trips are sometimes made to gardens during the flowering seasons, to a temple for worship or to witness a religious procession. But upon all occasions she is chaperoned. To go out with young men by themselves for a walk or a ricie would shock the people as much as it would a nice old French aunt. Exceptions are made to this rule of near relations and intimate friends of the family in case of parties. Judged from the western standpoint, none of the above so-called enjoyments would appeal very strongly, but to a Chinese girl she would be lucky to have one every now and then.

The moral teaching is chiefly derived from two sources, namely: from the books she has studied and from parental teachings. If she is an untutored girl then her moral ideas are acquired chiefly from moral stories or through the incidents of daily life. Chinese folk-lore is rich with anecdotes and stories, and a few of them would expound certain morals as definitely as Esop's fables do. Religious training is often no more than a series of minor household duties connected with sacrifices to gods and ancestors. On very rare occasions, young girls come into contact with Buddhist monks at masses either said at the house or at the monastery. These monks have often proven to be men of the world, and the learned ones are able to expound the doctrines as emphasized by Buddhism in a very convincing manner. But what has Buddhism 
done for Chinese womanhood? It has degraded it. As long as the numerous superstitions of this religion and others remain in the Middle Kingdom, Chinese women will never be placed upon an equal standing with men. Therefore, the first duty is to enlighten the darkened minds, and with this enlightenment, superstitions will take their natural flight. It is needless for the writer to say, that only Christianity can accomplish this tremendous task, no human power ever can.

\section{Engagement and Marriage}

Foot-binding is the first landmark to a girl at the age of five, the other two landmarks of greater importance are engagement and marriage at the age of twelve to fourteen and sixteen to twenty, respectively. From these, the boys also are not exempted; only such a catastrophe is with them deferred by two to four years. Marriage is a universal custom in China, and spinsters are rare.

Marriages are arranged by parents. This is most unreasonable, viewed from the western standpoint, but if we give it a little consideration, this social custom is quite rationally evolved. $\mathrm{Be}$ it understood, that engagements and marriages are much earlier in China, and therefore to expect a girl of twelve or fourteen to make a free choice of her own would be disastrous. Therefore, in the West a law raises the age of consent, and in the East, paternalistic assistance comes to the rescue (II A, III A. B). While it is generally acknowledged that a girl should not marry earlier than eighteen, oftentimes, due to the desire of a grandfather or a sick parent on either side, marriages are hastened. In compliance to the last wish of such a parent (II A), youths are united in their early teens, and this is made feasible by the communistic family life (III A) or else the wherewithal for self-support could not be earned by the youthful bridegroom.

With regard to what part the personal consent of the parties thus united will play, the wishes of the parents will determine. Generally they alone would decide, but sometimes an opportunity for interview between the parties might be arranged. As parents would reasonably select a party of the same station of life and pay some attention to personal appearance and temperament, the youthful parties could be reasonably expected to give a blushing consent. The chief reasons why they do not protest and show so 
much insubordination as a western youth would, are first, because they are young, and second, because they never had anyone of their own choice in view. It is not Romeo and Juliet, but the story of The Tempest universalized. Both the boy and the girl accept the other as the first love and as soon as they are united, each is willing to go half way to meet the wishes of the other. In addition to this, the difficulty to obtain a divorce further increases the mutual desire to live peacefully together. Marriage in the West often means the removal of sentimental masks of mutual considration; while in the East, it is the beginning of love-making.

To sum up briefly, we cannot say exactly that the children have no voice in the engagement, but as a fact they have nothing to say, being young and having no one else in view; neither can we say that marriage is not sacred, for only the first wife enjoys the full privileges of a wedding ceremony and this binding tie is very difficult to annul; nor can we say there is no love, although no party ever openly admits it. Even foreign critics say that love does exist only in a manner that is to be taken for granted.

\section{E. Her Married Life}

The married life of a Chinese girl is doublefold, namely: her relation to her husband and to his family. She is married to the family (II A), more than to her husband, as he is often so young that he is merely a student or an apprentice. The bride is received into the family as an additional child to be trained in the duties of life. She is indeed no mistress in the house. Why should she and how could she be? The relation of a wilful bride and an unreasonable mother-in-law can assume all the critical degrees of such strained relations. But if the girl knows her duties as a daughter-inlaw and fully realizes as most girls do, that she is merely on the par with her junior husband in his father's home, then things can proceed smoothly (II A). In a country where marriage is so early and education so limited among girls, to give control of the household to the inexperienced brides would wreck many a home.

This paternalistic and sometimes galling supervision is only reduced when the son becomes a self-supporting man or when the bride becomes mother to a son. It is motherhood and not wifehood that increases the privileges of independence in China. Wives are given to sons by parents that they may have an additional junior to 
serve them. The old people expect service from the young who in turn may expect the same from their juniors later on, but not while seniors are still living in the same household-in a word, family solidarity rests upon obedience and service to the elders (III A). In contrast to this, we find in the West later marriages by personal choice, while the parents resign themselves to a lonesome old age, alleviated only by an occasional visit from their children and grandchildren (III). Communistic family life oppresses the young wife and individualistic life sends the old widowed mother to a boarding house or a home.

Another phase of a woman's life which may possibly fall upon her is widowhood. There is no greater calamity which can befall a Chinese woman than that of early widowhood. Of the four great virtues, patriotism, filial piety, fidelity and righteousness, to which monuments are erected all over the land, fidelity of women is the most commemorated. The moral reasons for this custom are not far to seek, but the practice of it is the most pitiful. Widows that have children and are in good circumstances would never think of remarrying, but the pitiful aspect is the struggle of poor widows practising fidelity.

\section{F. Motherhood and Old Age}

In the East, motherhood is the crowning period of her life in spite of cares for the young and worries over household affairs (II A, B). Old age is a continuation of motherhood, then she rules supreme in the family in the absence of her husband. Her past sufferings, experiences and maternal cares combine to make her a matron obeyed by her children and respected in the community.

In conclusion, a Chinese girl's life has none of the privileges and pleasures of her western sister. She has less education and social knowledge, but she is taught to be filial and self-sacrificing. This paternalistic policy assures her of marriage and she is not expected to earn her own living. The western sister is better educated and more independent, but she is expected to take care of herself.

Communistic life is conservative and weak as compared with the individualistic (III A), but progress has been bought with the trying struggles of self-supporting girls and bachelor maids. No doubt, with the coming of more universal education and better 
economic life in China, the individual will be raised. Already, among the rising generation, constant rebellions of children against parental authority in early engagement and marriage are heard of (II A, B). Truly, the problem of the Chinese girl is a great one and nothing will solve it except that which will raise the standard of womanhood. Education alone does not accomplish it, for go back to the days when Rome and Babylon and Egypt were in the height of their education; what was the condition of womanhood in those days? It was demoralized beyond words. Therefore, the only solution to this tremendous problem is the widespreading of Christianity and Christian education. If the readers of this short and incomplete article could only go with the writer, first to a nonChristian home and then to a Christian home in China, even the most bigoted could see the difference and also find the factor which brings about this change-for to be a Christian in China is to live as one. 